\title{
POLITIK AKOMODATIF DALAM MASYARAKAT MULTI AGAMA
}

\author{
Katon Galih Setyawan ${ }^{* 1}$, Kusnul Khotimah ${ }^{2}$ \\ ${ }^{1}$ Program Studi Sosiologi, Universitas Negeri Surabaya, Surabaya, Indonesia \\ Email: katonsetyawan@unesa.ac.id \\ ${ }^{2}$ Program Studi Pendidikan IPS, Universitas Negeri Surabaya, Surabaya, Indonesia \\ Email: kusnulkhotimah@unesa.ac.id
}

\begin{abstract}
Abstrak
Kepentingan politik dan ekonomi diperuncing menjadi masalah agama banyak terjadi di Indonesia. Bahkan pertentangan dengan latar belakang agama di Jawa Timur sangat tinggi terjadi dan masyarakat Jawa Timur menduduki peringkat kedua sebagai masyarakat intoleran di Indonesia.Namun tidak demikian di Desa Resapombo yang multiagama mereka hidup rukun dan berdampingan tanpa adanya konflik terbuka di tengah-tengah masyarakat. Oleh karena itu pada penelitian ini mengambil fokus penelitian dengan mengacu pada bagaimana peran BPD dan LPMD dimaknai oleh masyarakat Desa Resapombo dalam mengelola kerukunan antar umat beragama. Penelitian ini menggunakan perspektif interaksi simbolik Blumer yaitu interaksi sosial dapat dipahami melalui makna yang ditafsirkan oleh aktornya. Penelitian ini menggunakan metode penelitian kualitatif dengan pendekatan fenomenologi.Di dalam membina kerukunan antar umat beragama terjadi proses sosial yang panjang dan menjadi membudaya saat ini dan dimaknai atau ditafsirkan sendiri oleh pelakunya dan itu dapat dikatan sebagai kearifan localdalampoltik mereka sendiri. Proses sosial itu dapat berupa beberapa kegiatan yang bersifat kegotongroyongan dan musyawarah mufakat.Dengan adanya lembaga resmi desa berupa BPD dan LPMD yang menjadi tempat akomodatif untuk menampung semua kepentingan politik di tingkat desa.
\end{abstract}

Kata kunci:Kerukunan, akomodasi politik, masyarakat multiagama

\begin{abstract}
Tapered political and economic interests have become a religious problem that is prevalent in Indonesia. Even opposition to the religious background in East Java is very high and the East Java community is ranked second as an intolerant society in Indonesia. But not so in the multi-religious Resapombo Village they lived in harmony and side by side without any open conflict among the community. Therefore in this study the focus of the study was based on how the role of the BPD and LPMD was interpreted by the Resapombo Village community to play a role in managing inter-religious harmony. This study uses the perspective of Blumer symbolic interaction, namely social interaction can be understood through the meaning interpreted by the actor. This study uses qualitative research methods with a phenomenological approach. In fostering harmony between religious communities a long social process takes place and becomes entrenched nowadays and is interpreted or interpreted by the perpetrators themselves and it can be claimed as their own local wisdom. The social process can take the form of several mutual cooperation activities and consensus agreements. with the existence of official village institutions in the form of BPD and LPMD which are accommodative places to accommodate all political interests at the village level.
\end{abstract}

Keywords: Harmony, political accommodation, religion plural society

Submited: 19-03-2019; Accepted: 27-04-2019; Published: 30-04-2019

*Korespondensi: Program Studi Sosiologi, Universitas Negeri Surabaya Ketintang

Jl. Ketintang, Ketintang, Gayungan, Kota Surabaya, Jawa Timur 60231

Email: katonsetyawan@unesa.ac.id 


\section{2| The Journal of Society and Media 3(1)}

\section{PENDAHULUAN}

Konflik sosial yang dilatarbelakangi oleh perebutan sumber daya ekonomi dan politik, namun diperuncing oleh perbedaan agama (atau bahkan etnik) dewasa ini semakin banyak terjadi di Indonesia (Hidayat 2017). Diawali dengan konflik Ambon, konflik Poso, konflik Sampit sampai konflik terbaru adalah konflik Lampung dan konflik Sumbawa. Semua konflik yang terjadi berawal pada ketimpangan ekonomi dan politik yang diperuncing pada isu-isu perbedaan agama(Muzaki 2018; Suryana 2011). Isu perbedaan agama sampai saat ini masih menjadi isu yang "cantik" untuk dilempar ke publik konflik dan isu perbedaan agama akan sangat besar eksesnya kepada publik seperti pelarangan peribadatan di Gereja HKBP Filadelfia di Bekasi dan GKI Yasmin di Bogor, atau konflik dalam satu agama yaitu konflik Ahmadiyah di Bogor dan Mataram serta konflik Syiah di Sampang. Semua contoh itu menjadikan agama terkesan merupakan sebagai pembenar bagi penganutnya untuk melakukan tindakan kekerasan atau permusuhan terhadap kelompok lainnya yang tidak sepaham dengan atas nama agama (Faridah 2013; Muhdina 2015; Asri 2015).

Menurut laporan The Wahid Institute Tahun 2015 bahwa pelanggaran kebebasan beragama dan berkeyakinan setiap tahun selalu meningkat baik yang dilakukan oleh aparatur pemerintah maupun warga sipil lainnya. Jawa Timur menempati peringkat keempat pelanggaran kebebasanberagama dan berkeyakinan yang dilakukan oleh aparatur pemerintah, bahkan Jawa Timur menempati peringkat kedua sebagai masyarakat yang intoleran terhadap kebebasan beragama dan berkeyakinan. Tingginya pelanggaran terhadap kebebasan beragama dan berkeyakinan di Jawa Timur disebabkan karena pemerintah masih membatasi kehidupan beragama dari pada menjamin dan melindungi dalam kehidupan beragama di masyarakat.

Kehidupan masyarakat multiagama sangat rentan dengan adanya konflik horizontal, mengingat mereka terlahir sebagai umat yang berbeda pemahaman keagamaannya. Konflik antarumat beragama sangat mudah tersulut di dalam masyarakat. Selain konflik antarumat bergama, dewasa ini di masyarakat jugabanyak terjadi konflik dalam satu agama. Konflik antar umat beragama sangat rawan terjadi dan merupakan isu sensitif di dalam struktur masyarakat(Faridah 2013; Nawawi 2009). 
Gambaran konflik antarumat beragama ini tidak selalu ditemui di daerah dengan heteroginitas agama (Fauzi 2018). Perbedaan yang terjadi pada masyarakat multiagama yang rentan konflik, tidak terjadi pada masyarakat di Desa Resapombo, Kec. Doko, Kab. Blitar. Dari pengamatan awal masyarakat desa itu hidup dalam perbedaan agama yang sangat banyak dimana terdapat lima agama yang dianut oleh warga masyarakatnya yaitu Islam, Kristen, Katholik, Hindu dan Budha. Setiap agama memiliki tempat ibadahnya masing-masing dan letak tempat ibadah mereka tidak berjauhan dan berjumlah banyak. Kehidupan mereka sangat harmonis dengan setting kehidupan mereka di pegunungan dan mayoritas sebagaipetani di pinggir hutan. Realita sosial yang terjadi adalah kehidupan yang harmonis dengan berbagai kerja sama antar warga masyarakat desa dengan setting budaya Jawa Mataraman(Fidiyani 2013; Salahuddin 2008; Mansur 2017).

Dalam mengelola kerukunan antar umat beragama (Mutiah 2017) awalnya pemerintahan Orde Baru dalam hal untuk meminimalisasi konflik antar umat beragama adalah dibentuknya wadah resmi keagamaan seperti MUI, PGI, KWI, Walubi dan PHDI. Artinya ini adalah menyamakan semua agama dalam bentuk organisasi tersebut. Pemerintah orde baru pada waktu itu melakukan penyeragaman organisasi yang berlaku sejak dari pusat sampai daerah. Berbeda dengan konsep kearifan lokal yang terjadi di Desa Resapombo yang lebih pada menggunakan keberagaman agama dan melaui unsur-unsur kebudayaaan sebagai pengikatnya perbedaan. Ormas keagamaan sebagai tempat bertemunya identitas yang sama dan melembaga merupakan kekuatan massa yang dapat dimanfaatkan untuk kepentingan di atas. Ketika agama-agama yang berbeda ini menyemai dalam perangkat sosial, baik formal, maupun non formal, maka kewajiban untuk duduk bersama dalam perbedaan identitas itu harus terus diperjuangkan dalam memelihara kerukunan antarumat beragama di tengah pluralitas(Ahmad Munjin Nasih 2011).

Dalam menganalisis organisasi sosial, pengikut interaksi simbolik harus fokus pada tingkat mesostruktur. Tokoh yang mengembangkan ini adalah Maines (baca: Ritzer, 2003) yang menyoroti minat interaksionis pada struktur, institusi, dan organisasi, dengan menegaskan bahwa pengikut interaksionisme memang memiliki konsep seperti tatanan yang dinegosiasikan (negotiated order), batasan 


\section{4| The Journal of Society and Media 3(1)}

(constraint), tindakan kolektif (collectiveaction)dankomitmen kepadaorganisasi yang memungkinkan mereka menganalisis unit-unit sosial berskala besar (Smart 2011).

Dalam mempelajari organisasi sosial yang besar (Wahyudi 2017), interaksi simbolik masih dapat menjelaskan penstrukturan bidang-bidang organisasional dan sistem-sistem sosial budaya melalui negosiasi-negosiasi simbolik, sehingga mirip dengan negosiasi berskala lebih kecil. Bahkan sistem berskala besarpun pada akhirnya dilekatkan pada simbol-simbol yang digunakan orang dan interaksiinteraksi yang mereka lakukan saat menghadapi realitas-realitas lokal (kearifan lokal) (Smart 2011).

Dalam melihat negosiasi Maines (baca: Ritzer, 2011) untuk menganalisis makna maka makna tersebut dinegosiasikan. Negosiasi itu dimungkinkan karena manusia mampu memberi nama sesuatu, bukan hanya objek fisik, tindakan atau peristiwa namun juga gagasan yang abstrak. Akan tetapi, nama atau simbol yang digunakan untuk menandai objek, tidakan, peristiwa atau gagasan itu bersifat arbitrer (sembarang)(Rusydi and Zolehah 2018; Hadi 2017). Melalui simbol itulah manusia dapat berbagai pengalaman dan pengetahuan tentang dunia (Rijal 2011; Lestari 2015).

\section{METODE PENELITIAN}

Penelitian ini menggunakan metode penelitian kualitatif, yaitu penelitian yang bermaksud untuk memahami fenomena tentang apa yang dialami oleh subyek penelitian misalnya perilaku, persepsi, motivasi, makna dan tindakan. Secara holistik, dan dengan cara deskripsi dalam bentuk kata-kata dan bahasa, pada suatu konteks khusus yang alamiah dan dengan memanfaatkan berbagai metode alamiah (Moleong 2006). Penyajian data dari penelitian ini menggunakan format deskriptif yaitu dengan tujuan untuk menggambarkan, meringkaskan berbagi kondisi, berbagai situasi atau berbagai fenomena yang timbul di masyarakat, yang menjadi obyek penelitian itu, kemudian menarik kepermukaan sebagai suatu ciri atau gambaran tentang kondisi, situasi ataupun fenomena tertentu (Bungin 2001).

Penentuan subjek penelitian dilakukan dengan cara purposive sampling yaitu menentukan terlebih dahulu subjek penelitiannya dengan dibantu oleh Kepala Desa Resapombo. Jadi subjek penelitian ditentukan bersama Kepala Desa 
sejak awal penelitian dimulai. Selain itu setelah ditentukan bersama dengan Kepala Desa peneliti juga melakukan snowball saat penelitian jika dianggap subjek penelitian yang sebelumnya sudah ditentukan sulit untuk ditemui. Selanjutnya subjek penelitian yang telah diwawancarai adalah mereka yangdianggap mengetahui dan mengelola kerukunan antarumat beragama yang berstatus sebagai elite desa yaitu berasal dari perangkat desa dan tokoh BPD, tokoh agama, tokoh masyarakat, tokoh budaya dan tokoh pemuda.

Teknik analisis yang digunakan dalam penelitian ini adalah teknik analisis domain. Menurut Bungin (Bungin 2001) teknik tersebut digunakan "untuk menganalisis gambaran obyek penelitian secara umum atau di tingkat permukaan". Dalam konteks penelitian ini analisis domain digunakan untuk melakukan kategorisasi berdasarkan tema yang telah ditentukan dalam penelitian ini. Kategorisasi yang dimaksud adalah mengelompokkan bentuk-bentuk kesadaran diri yang tampak pada proses pengelolaan kerukunan antarumat beragama.

Teknik analisis domain memberikan hasil analisis yang luas dan umum, tetapi belum terinci serta masih bersifat menyeluruh. Oleh karena itu untuk mendapatkan gambaran secara lebih terinci lagi dipergunakan teknik analisis taksonomik. Menurut Bungin (Bungin 2001) teknik ini "terfokus pada domaindomain tertentu, kemudian memilih domain tersebut menjadi sub-sub domain serta bagian-bagian yang lebih khusus dan terperinci yang umumnya merupakan rumpun yang memiliki kesamaan”. Dalam konteks penelitian ini kategori berdasarkan domain kesadaran tersebut akan dirinci lagi menjadi sub-sub domaindengan memperhatikan atribut-atribut sosial dari subjek penelitian yaitu para tokoh agama, tokoh masyarakat dan perangkat desa.

Penelitian ini menggunakan teori interaksi simbolik Herbert Blumer untuk menganalisa tentang politikakomodatifdalammasyarakatmultiagama yang terjadi di daerah Blitar khususnya interaksi masyarakat dalam kehidupan berbangsa dan bernegara merespon kebijakan poitik lokal pemerintah desa.

\section{HASIL DAN PEMBAHASAN}

\section{Profil Desa}




\section{I The Journal of Society and Media 3(1)}

Masyarakat Desa Resapombo jika ditinjau dari keagamaan mayoritas beragama Islam. Umat Islam Resapombo berjumlah 6.439 jiwa, disusul oleh umat Katholik yang berjumlah 1.916. Tiga agama selanjutnya adalah Hindhu berjumlah 492 jiwa, Kristen Protestan berjumlah 195 orang dan terakhir adalah Budha yang berjumlah 111 orang. Dari kelima agama yang bisa dihitung secara jumlah kepala keluarga hanya Budha yang berjumlah 52 kepala keluarga, sedangkan agamalainnya tidak bisa dihitung secara jumlah kepala keluarga karena empat agama itubanyak terjadi pernikahan beda agama (Monografi Desa Resapombo, 2017). Menurut catatan data Monografi DesaResapombo tahun 2012 tidak tercatat warga yang menganut Aliran KepercayaanKepada Tuhan Yang Maha Esa, artinya semua warga desa memeluk agama formalatau agama resmi dari negara.

Tabel 1.MasyarakatDesaResapombomenurut Agama

\begin{tabular}{clr}
\hline No. & \multicolumn{1}{c}{ Agama } & Jumlah \\
\hline 1. & Islam & 6.439 \\
2. & Katholik & 1.916 \\
3. & Kristen Protestan & 195 \\
4. & Hindhu & 492 \\
5. & Budha & 111 \\
6. & AliranKepercayaan & 0 \\
\hline & Jumlah & 9.155 \\
\hline
\end{tabular}

Sumber: Data Monografi Desa ResapomboTahun 2017

Ditinjau dari tempat ibadah bisa dikatakan menyebar dan merata di setiaplingkungan. Umat Islam yang berjumlah sekian banyak memiliki sembilan masjiddan 21 musholla. Gereja Katholik ada sebanyak lima buah dan empat buah gerejaKristen Protestan. Sedangkan Pura dan Vihara masing ada satu buah. Hasil pengamatan peneliti menunjukkan adanya masjid dan gereja tersebar di seluruh dusun, semuanya ada. Berbeda dengan Pura dan Vihara yang hanya terdapat di satu dusun saja karena umat Hindhu dan Budha hanya mengumpul di satu lokasi. Pura berada di Dusun Resapombo karena umat Hindhu hanya terdapat di Dusun Resapombo dan Vihara terdapat di Dusun Salamrejo karena umat Budha hanya mendiami wilayah Dusun Salamrejo. Terdapat beberapa tempat ibadah yang saling berdekatan seperti Masjid Jami' Ta'awun hampir berhadapan dengan Gereja Katholik Santo Fransiscus Asisi Resapombo, Pura Hindhu berdampingan dengan Gereja GPdI Tiberias, Vihara berdekatan dengan Gereja Pantekosta dan Masjid Salamrejo. Dengan tempat ibadah yang saling berdekatan memiliki sisi positif yaitu menunjukkan kekompakan dan toleransi yang besar. 


\section{Karakteristik Masyarakat Desa}

Masyarakat Desa Resapombo sebagai bagian dari masyarakat Jawa masih menganut dan melestarikan tradisi masyarakat Jawa. Tradisi tersebut dapat berupa seni tradisional Jawa yang sampai sekarang masih dilestarikan, seperti adanya kelompok karawitan Gagak Lodra, kelompok macapat Ngesthi Raras dan beberapa seniman dhalang yang tinggal di desa ini. Kelompok karawitan GagakLodra merupakan kelompok kesenian besar yang mencakup seni gamelan, senipedhalangan dan seni jaranan.

Selain adanya kelompok kesenian yang masih melestarikan seni budaya Jawa, peneliti melihat masyarakat masih menggunakan bahasa Jawa halus (basakrama) ketika mereka berbicara dengan orang yang baru dikenalnya. Penelitidalam hal ini berusia jauh lebih muda dengan para informan tapi ketika bertamuuntuk wawancara dengan para informan mereka semua pada awalnya menggunakan bahasa Jawa halus. Hal ini sebagai bentuk penghormatan kepada orang yang baru dikenalnya. Seperti dalammenyebut "anda" kepada peneliti, para informan menggunakan kata panjenengan. Panjenengan adalah bahasa Jawa yang paling halus untuk menyebut kamu/anda dan biasanya ini digunakan untuk menyebut kalangan orang yang sangat dihormati, orang tua atau kalangan bangsawan. Hal inilah salah satu bentuk njawani. Njawani itu berarti mbeneh, yang dimaksud mbeneh adalah mengerti. Jadi orang yang Jawa itu adalah orang yang mengerti.Semua itu adalah bentuk menghormati tamu dan orang yang baru dikenalnya.

Kedatangan peneliti ke rumah-rumah informan, bagi informan bukan merupakan beban karena ketika ada tamu yang datang ke rumahnya itu dianggap sebagai penghormatan dan bisa disebut sebagai sanja. Sanja merupakan implementasi dari falsafah srawung (bersilaturrahmi). Dalam tradisi masyarakat Jawa sanja merupakan bentuk silaturahmi yang dapat mempererat tali persaudaraan diantara mereka walaupun tidak ada tali persudaraan sedarah.

Selain itu tradisi masyarakat Jawa lainnya yang masih dijalankan adalah tradisi petungan yaitu tradisi untuk menghitung hari baik jika akan mengadakan kegiatan seperti pernikahan atau membangun rumah. Tradisi petungan merupakan 


\section{8| The Journal of Society and Media 3(1)}

ilmu numerologi Jawa yang sudah sangat lama dijalankan oleh masyarakat Jawa. Ajaran budaya masih banyak yang memegang teguh, karena masyarakat Jawa bisa membedakan antara ajaran agamadan ajaran budaya(Geertz 2013).

Selain itu petungan hari dalam menentukan hari baik juga masihdilaksanakan oleh Thomas Ponijo. Bahwa petungan baik merupakan warisanbudaya nenek moyang orang Jawa, yang semua itu sudah dititeni. Menentukanhari baik bukan saja dengan cara petungan tetapi ada waktu-waktu tertentu yangmemang dilarang untuk melaksanakan hal-hal penting. Thomas Ponijo menjelaskan bahwa bulan Sela merupakan bulan yang tidak baik untukmelaksanakan hajat apapun juga termasuk mendirikan rumah. Pada saat penelitimemulai penelitian di Desa Resapombo dan kemudian tinggal di rumah ThomasPonijo, baru saja informan mendapat kesusahan karena adik ipar informanmeninggal dunia karena kecelakaan kerja, bahkan pada saat peneliti hari pertamatinggal di rumah Thomas Ponijo pada saat itu tepat slametan peringatan tujuh harikematian tersebut.

Informan menjelaskan bahwa kematian adik iparnya disebabkan karenakecelakaan kerja, yakni jatuh dari ketinggian. Adik ipar informan bekerja sebagaitukang bangunan yang sedang membongkar rumah tetangganya. Pada saat itubelum lama memulai membongkar rumah, baru menurunkan rangka atap rumahsudah terjadi kecelakaan tersebut. Sebenarnya ketinggian rumah rumah tidakterlalu tinggi kurang dari tiga meter, sehingga jika dinalar secara akal manusiaseharusnya tidak sampai pada kematian jika jatuh dari ketinggian tersebut. Informan percaya bahwa kecelakaan ini karena memang melanggar aturan Jawa bahwa tidak diperbolehkan untuk melaksanakan hajat tertentu pada bulan Sela termasuk membongkar rumah. Sehingga setelah kejadian itu terjadi pemilik rumah menjadi bahan omongan tetangga. Banyak yang menyangka "Kaya ora anadina liya" (seperti tidak ada hari lain). Memang masyarakat Jawa akanmenghindari bulan Sela untuk mengadakan hajatan.

Tradisi Jawa semacam ini masih banyak dilestarikan oleh masyarakat Desa Resapombo. Jauh berbeda dengan aturan agama yang tidak mengenal saat-saat tertentu untuk dilarang mengadakan hajatan. Agama tidak melarang untuk mengadakan hajatan pada bulan Sela. Aturan semacam itu merupakan bagian dari budaya Jawa yang telembagakan dalam kehidupan masyarakat Jawa. Lembaga budaya tersebut dianut sebagai acuan hidup masyarakat Jawa yang lintas agama. 
Ketika berbicara budaya Jawa masyarakat Desa Resapombo menunjukkan identitasnya sebagai masyarakat Jawa, mereka meninggalkan identitas agama masing-masing.

Masyarakat Desa Resapombo yang Njawani inilah menjadi menarik untuk didiskusikan dalam ranah akademis. Budaya Jawa sebagai bagian hidup masyarakat Desa Resapombo yang multi agama bisa dijadikan sebagai unsur untuk mengelola kerukunan antar umat beragama. Artinya setiap masyarakat yang secara agama berbeda mereka masih memiliki identitas yang sama yaitu sebagai masyarakat Jawa. Hal ini dapat dijelaskan bahwa terdapat diferensisi sosial secara agama dan terdapat satu kesamaan unsur budaya dalam kearifan lokal. Kearifanlokal yang merupakan bagian dari struktur sosial masyarakat dianggap bisa untuk mengelola kerukunan antar umat beragama dalam fakta terdapat perbedaan agama di masyarakat(Tafsir 2000; Khotimah 2011).

\section{BPD dan LPMD: Institusi Dialog Resmi, Tempat Akomodasi Kepentingan Politik Setiap Agama}

Kepentingan setiap agama tentu berbeda antara satu dengan yang lainnya terutama kepentingan politik, walaupun hanya politik di tingkat desa. Pemerintahan Desa Resapombo banyak diduduki oleh perangkat yang beragama Katholik dan Islam. Sebagai penyeimbang kekuatan Pemerintahan Desa maka dibentuk BPD, dan sebagai mitra pelaksana kebijakan dibentuk LPMD. Kedua lembaga desa itu diisi dengan komposisi beragam agama yang ada. Sehingga seluruhnya terakomdasi dengan baik. Walaupun untuk unsure BPD tidak ditentukan mengenai keterwakilan agama yang ada, karena BPD mewakili secara kewilayahan atau dusun.

Tugas BPD bersama kepala desa adalah membahas rancangan peraturan desa yang mengatur keberlangsungan pembangunan di desa, termasuk di dalamnya kebijakan-kebijakan strategis desa. BPD berjumlah 11 orang dengan dipimpin oleh seorang ketua, seorang wakil ketua dan seorang sekretaris sedangkan lainnya menjadi anggota. BPD awalnya dipilih melalui pemilihan secara terbuka seperti pemilihan umum. Setiap dusun memiliki jatah kursi perwakilan di BPD proporsional sesuai dengan jumlah penduduk. Semakin banyak jumlah penduduk maka semakin banyak jumlah anggota BPD yang 
dipilih. Anggota BPD yang terpilih kebanyakan adalah tokoh masyarakat yang memiliki pengaruh di masyarakat.

Posisi BPD sangat strategis, selain membahas rancangan peraturan desa, BPD dengan kewenangnannya juga bisa memberhentikan kepala desa dan juga mengawasi tugas kepala desa. Tugas ini sangat strategis dan berperan penting dalam proses politik di desa. Dengan posisi yang sejajar dengan kepala desa, BPD bisa mempengaruhi kebijakan desa. Anggota BPD yang merupakan representasi atas kewilayahan atau dusun juga terdiri dari berbagai macam agama. Menurut Raharjo (Rahardjo 2004) bahkan di beberapa tempat lain anggota BPD banyak diisi oleh calon kepala desa yang kalah sehingga BPD berperan cenderung melakukan peran secara berlebihan. Namun BPD yang berperan berlebihan tidak terjadi di Desa Resapombo mengingat seluruh anggota BPD bekerja untuk kepentingan masyarakat, bukan untuk kepentingan kelompok atau diri sendiri.

Sejak awal pembentukan BPD memang tidak disengaja atas keterwakilan agama, namun karena setiap dusun memiliki basis agama yang berbeda maka keanggotaan BPD saat ini sudah bisa mencakup paling tidak tiga agama yaitu Islam, Katholik dan Kristen Protestan. Dua agama lainnya tidak memiliki wakil di BPD karena tidak memiliki jumlah umat yang banyak untuk mengantarkan wakilnya duduk di kursi BPD. Seperti Hindhu yang terkonsentrasi di Dusun Resapombo kalah jauh dari umat Islam dan Katholik. Sedangkan Budha yang berada di Dusun Salamrejo juga hanya sedikit jumlahnya, kalah jumlah dengan Islam dan Katholik.

Dengan demikian BPD bisa digunakan sebagai wadah dialog resmi para tokoh untuk mengelola kerukunan antar umat beragama. BPD selain berfungsi sebagai lembaga politik juga berfungsi sebagai lembaga sosial. Tokoh yang ada di dalam BPD bisa memperjuangkan aspirasi untuk mengelola kerukunan antar umat beragama. Seperti anggota BPD yang berasal dari Dusun Resapombo yang beragama Kristen Protestan Eko Santoso/Bambung (39) menyatakan akan terus mengadakan diskusi secara baik kepada tokoh agama Islam mengenai pengaturan pengeras suara masjid agar tidak menganggu kenyamanan umat agama lain. Memang pihak masjid sekarang sudah mengatur waktu dan arah pengeras suara masjid agar tidak mengganggu umat agama lain ataupun tempat ibadah agama lain, hanya saja terkadang pihak masjid lupa bahwa sering mengadakan kegiatan pada hari minggu yang bersamaan dengan kebaktian di gereja. Ini nantinya perlu 
ada kesadaran bersama untuk mngelola agar tidak terjadi konflik karena terlalu seringnya kegiatan masjid yang menggunakan pengeras suara yang bersamaan dengan kegiatan kebaktian di gereja.

Dialog resmi bersama dengan tokoh-tokoh agama dianggap tidak memiliki resiko konflik karena diadakan dalam forum resmi semacam BPD dan bersama tokoh-tokoh yang memiliki pengetahuan serta kesadaran yang tinggi akan kebutuhan kerukunan antar umat beragama. Berbeda jika dialog keagamaan dilakukan dengan warga biasa yang cenderung memiliki pemikiran fanatic yang sempit terhadap pemahaman agamanya. Tentu ini bisa menimbulkan konflik terbuka mengingat mereka akan memakasakan kehendaknya. Pemahaman seperti ini sudah sangat dipahami oleh beberapa tokoh termasuk diantaranya adalahSukardi (50) tokoh pengusaha beragama Islam, yang menyatakan berbicara kerukunan dan diskusi agama sebaiknya dilakukan oleh orang yang memiliki SDM yang baik.

Lembaga selanjutnya adalah LPMD atau Lembaga Pemberdayaan Masyarakat Desa. Lembaga ini merupakan lembaga mitra kerja kepala desa dalam menjalankan kebijakan desa yang telah dibahas antara kepala desa dengan BPD. Anggota LPMD dipilih secara musyawarah mufakat antara perangkat desa dan disetujui oleh BPD. Dalam lembaga ini seluruh agama telah masuk di dalamnya, sesuai dengan keahlian masing-masing. Keterwakilan agama di LPMD pada dasarnya bukan tujuan utama dalam pemilihan anggota LPMD, tetapi karena keahlian dan kemampuan anggota yang dipilih tersebut.

Menurut Ketua LPMD Resapombo, Saiful Karyadi (49) semua agama telah terakomodasi di semua bidang Pemerintahan Desa Resapombo, mulai perangkat desa, BPD, LPMD, RT, RW, PKK dan Karang Taruna. Inilah bentuk akomodasi kepentingan politik setiap agama di tingkat desa. Dalam setiap lembaga yang ada sering diadakan diskusi yang berkelanjutan untuk membahas masalah-masalah dan isu yang sedang berkembang. Ini merupakan bentuk kerukunan yang terstruktur karena dilembagakan. Perangkat desa sebagai kepanjangan tangan pemerintah di tingkat desa, berperan sebagai pelayan masyarakat yang baik. BPD sebagai parlemen di tingkat desa bertugas untuk bersinergi dengan perangkat desa untuk menyusun kebijakan desa. LPMD merupakan mitra kerja perangkat desa untuk menjalankan program-program kerja. RT dan RW merupakan satuan 


\section{2| The Journal of Society and Media 3(1)}

kewilayahan terkecil yang berada di lingkunganwarga. Keterlibatan warga dalam satuan RT dan RW memang lebih terlihat dan aktif mengingat bentuk mereka yang lebih kecil.

Tidak semua tokoh agama terlibat langsung dalam setiap proses pembangunan di desa, karena mereka tidak masuk dalam lembaga desa. Hanya terdapat beberapa saja yang masuk dalam lembaga desa. Tokoh agama banyak dilibatkan ketika ada masalah yang menyangkut dengan perselisihan antar agama atau sesama dalam satu agama. Permasalahan antar agama yang berskala besar sampai saat ini tidak pernah terjadi di Desa Resapombo. Kerja sama antar umat beragama dan kerukunannya sudah sangat baik. Tingkat toleransi yang tinggi mengakibatkan setiap umat beragama memahami perbedaan dan tidak menjadikan perbedaan sebagai kendala untuk melakukan kerjasama. Kerja sama dalam bidang sosial juga terjadi lintas agama, banyak orang Islam yang mempekerjakan orang yang beragama lain, begitu juga sebaliknya. Sukardi (50) pengusaha penyulingan minyak atsiri yang beragama Islam memperkerjakan orang yang beragama Katholik dan Hindhu. Salah satu cabang usaha lainnya adalah sebuah station radio yang bernama Wahyu Wijaya FM juga memperkerjakan penyiar yang beragama Katholik.

Berbeda dengan konflik dalam seagama yang pernah terjadi seperti yang tertulis di atas terkait dengan penyebaran aliran JAT. Dalam penyelesaian konflik seagama cukup diselesaikan dengan melibatkan tokoh agama yang bersangkutan bersama perangkat desa. Dalam konflik seagama tokoh agama lain jaga jarak agar tidak terlibat secara langsung di dalamnya, karena jika ikut-ikut dalam konflik seagama akan menimbulkan kecurigaan yang berlebih dari agama yang sedangberkonflik. Tindakan semacam ini perlu untuk dilaksanakan karena konflik dalam seagama merupakan urusan rumah tangga agama masing-masing. Tugas selanjutnya bagi tokoh agama adalah mengembalikan pemahaman agama warga yang telah masuk ke dalam aliran JAT untuk kembali ke ajaran seperti semula yang toleran. Setelah permasalahan JAT di Dusun Salamrejo dianggap selesai maka warga yang pernah menjadi anggota JAT atau masih menjadi anggota JAT saat ini masih menjadi pengawasan pihak kepolisiandibantu oleh perangkat desa, dan tokoh masyarakat serta tokoh agama.

Hasilpenelitianinimenunjukkanbahwadistribusikekuasaankepadaelit agama di 
baik.Kompetisi social dan konflik antar umat beragama dapat diminimalisasi dengan distribusi kekuasaan. Distribusi kekuasaan ini dilakukan dengan menempatkan semua tokoh agama dalam institusi-institusi pemerintah desa. Institusi tersebut antara lain adalah pemerintah desa, BPD dan LPMD.

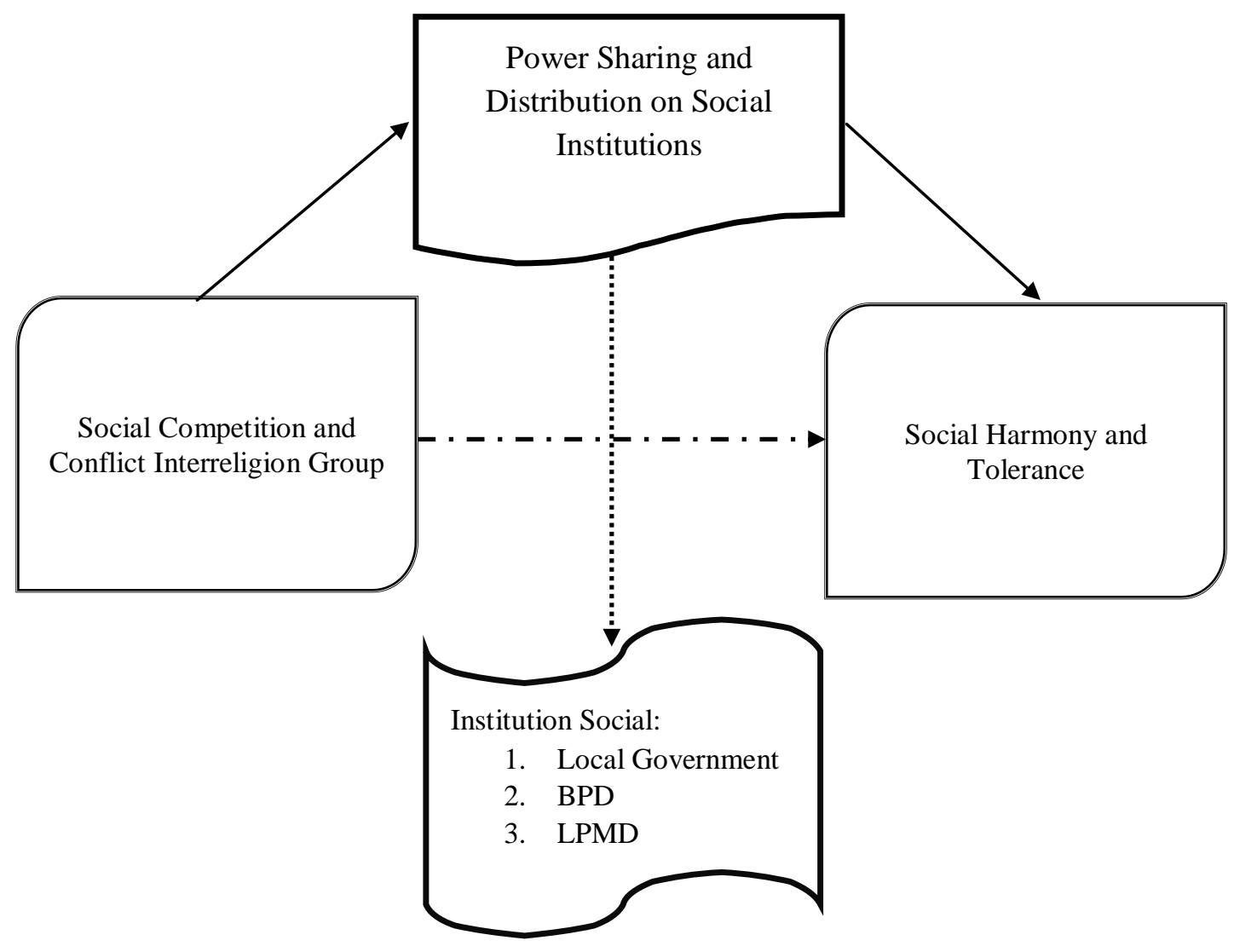

Bagan 1.Alur berfikir proses terbentuknya masyarakat harmoni

\section{KESIMPULAN}

Mengelola kerukunan antar umat beragama bukan perkara yang mudah, karena semuanya memerlukan proses yang panjang dengan kesadaran yang tinggi sebagai masyarakat majemuk. Di dalam membina kerukunan antar umat beragama terjadi proses sosial yang panjang dan menjadi membudaya saat ini.dengan adanya lembaga resmi desa berupa BPD dan LPMD yang menjadi tempat akomodatif untuk menampung semua kepentingan politik di tingkat desa.

Kepentingan setiap agama tentu berbeda antara satu dengan yang lainnya terutama kepentingan politik, walaupun hanya politik di tingkat desa. Pemerintahan Desa Resapombo banyak diduduki oleh perangkat yang beragama Katholik dan Islam. Sebagai penyeimbang kekuatan Pemerintahan Desa 
makadibentuk BPD, dan sebagai mitra pelaksana kebijakan dibentuk LPMD. Kedua lembaga desa itu diisi dengan komposisi beragam agama yang ada. Sehingga seluruhnya terakomdasi dengan baik. Walaupun untuk unsur BPD tidak ditentukan mengenai keterwakilan agama yang ada, karena BPD mewakili secara kewilayahan atau dusun.

Demokrasi dapat dilaksanakan dengan sebaik-baiknya dalam masyarakat yang bernegara maka akan menghasilakan masyarakat yang puas (Gantung 2003). Jika ditinjau dari akomodasi kepentingan politik setiapagama di pemerintahan Desa Resapombo, maka hanya ada dua agama yang terakomodasi di perangkat desa yaitu Islam dan Katholik. Sedangkan tiga agama lain tidak terakomodasi dengan baik. Namun untuk mengakomodasi tiga agama yang belum masuk di perangkat desa maka terdapat dua institusi desa lainnya yang mengakomodasinya yaitu BPD dan LPMD dimana di dalam dua institusi itu semua agama terakomodasi.

\section{REFERENSI}

Ahmad Munjin Nasih, Dewa Agung Gede Agung. 2011. "Harmoni Relasi Sosial Umat Muslim Dan Hindu Di Malang Raya." Masyarakat, Kebudayaan Dan Politik 24(2):142-50.

Asri, M. Yusuf. 2015. "Komunikasi Dialog Merawat Kerukunan Umat Beragama Di Indonesia.” Wacana Jurnal Ilmiah Ilmu Komunikasi 14(2):133-53.

Bungin, Burhan. 2001. Metodologi Penelitian Sosial. Surabaya: Airlangga University Press.

Faridah, Ika Fatmawati. 2013. "Toleransi Antar Umat Beragama Masyarakat Perumahan.” Jurnal Komunitas 5(1).

Fauzi, Agus Machfud and A Sudrajat and A Affandi and A Raditya. 2018. " Maintaining Identity Political Culture In Indonesia." Journal of Physics: Conference Series. 953(1): 1-6.

Fidiyani, Rini. 2013. "KERUKUNAN UMAT BERAGAMA DI INDONESIA (Belajar Keharomonisan Dan Toleransi Umat Beragama Di Desa Cikakak, Kec. Wangon, Kab. Banyumas).” Jurnal Dinamika Hukum 13(3):465-82.

Gantung, Johan. 2003. Studi Perdamaian: Perdamaian Dan Konflik, Pembangunan Dan Peradaban. Surabaya: Pustaka Eureka.

Geertz, Clifford. 2013. Agama Jawa: Abangan, Santri, Priyayi Dalam Kebudayaan Jawa. Depok: Komunitas Bambu.

Hadi, Rahmini. 2017. "POLA KERUKUNAN UMAT BERAGAMA DI 
BANYUMAS.” IBDA 14(1):66-78.

Hidayat, Medhy Aginta. 2017. "Ibadat, The Body And Identity: Islamic Rituals and The Contrustion of Muslim Identity." The Journal of Society and Media 1(2): $1-17$

Khotimah. 2011. "Dialog Dan Kerukunan Antar Umat Beragama.” Jurnal Ushuluddin 17(2):214-24.

Lestari, Gina. 2015. "BHINNEKHA TUNGGAL IKA: KHASANAH MULTIKULTURAL INDONESIA DI TENGAH KEHIDUPAN SARA." Jurnal Pendidikan Pancasila Dan Kewarganegaraan 28(1):31-37.

Mansur, Syafi'in. 2017. "KERUKUNAN DALAM PERSPEKTIF AGAMAAGAMA DI INDONESIA.” Aqlania 8(02):27-72.

Moleong, Lexi J. 2006. Metodologi Penelitian Kualitatif. Bandung: PT Remaja Rosadakarya.

Muhdina, Darwis. 2015. "KERUKUNAN UMAT BERAGAMA BERBASIS KEARIFAN LOKAL DI KOTA MAKASSAR." Jurnal Diskursus Islam 3(1):20-36.

Muzaki, Muzaki. 2018. "PARTISIPASI TOKOH MASYARAKAT DALAM TOLERANSI UMAT BERAGAMA." KOMUNIKA: Jurnal Dakwah Dan Komunikasi 4(1):160-77.

Mutiah. 2017. "Membangun Sistem Komunikasi Indonesia Yang Kolektif Lewat Media Tradisional." The Journal of Society and Media 1(2): 75-85

Nawawi, Adlan. 2009. "Pluralitas Dan Kemandirian Dalam Keragaman.” Jurnal Bimas Islam Depag RI 2(2):112-28.

Rahardjo. 2004. Pengantar Sosiologi Pedesaan Dan Pertanian. Yogyakarta: Gadjah Mada University Press.

Rijal, M. Khoirul. 2011. "Kerukunan Antar Umat Beragama: Studi Atas Kerukunan Antar Umat Di Dusun Ngepeh, Desa Rejoagung, Kec. Ngoro, Kab. Jombang." Universitas Airlangga.

Rusydi, Ibnu and Siti Zolehah. 2018. "Makna Kerukunan Antar Umat Beragama Dalam Konteks Keislaman Dan Keindonesian.” Jurnal For IIlamic Studies 1(1):170-81.

Salahuddin, Marwan. 2008. "Mengenal Kearifan Lokal Di Klepu Ponorogo; Praktik Hubungan Sosial Lintas Agama Dan Mekanisme Pencegahan Konflik", Dalam Irwan Abdullah et.Al., Agama Dan Kearifan Lokal Dalam Tantangan Global. Yogyakarta: Sekolah Pascasarjana UGM dan Pustaka Pelajar.

Smart, George Ritzer dan Barry. 2011. Handbook Teori Sosial. (Penerjemah: Imam Muttaqien, Derta Sri Widowatie Dan Waluyati). Bandung: Penerbit 
16| The Journal of Society and Media 3(1)

Nusa Media.

Suryana, Toto. 2011. "Konsep Dan Aktualisasi Kerukunan Antar Umat Beragama.” Pendidikan Agama Islam -Ta'lim 9(2):127-36.

Tafsir. 2000. Hubungan Budaya Jawa Dan Islam, Pengaruhnya Terhadap Politik Di Indonesia”, Dalam Darori Amin et.Al., Islam Dan Kebudayaan Jawa. Yogyakarta: Media Gama.

Wahyudi, Agus. 2018. " Ketika Membunuh Menjadi Sebuah Penyelesaian: Sebuah Tinjauan Fenomenologis Mengenai Tindakan Seseorang Melakukan Pembunuhan." The Journal of Society and Media 2(1): 13-30 